\title{
The coastal community perspective of the mangrove ecosystem management in Karawang Regency, West Java, Indonesia
}

\author{
Yan A. Nugraha ${ }^{1}$, Sulistiono ${ }^{2, *}$, Handoko Adi Susanto \\ ${ }^{1}$ Study Program of Coastal and Marine Resources Management, Graduate School, Bogor Agricultural \\ University, Bogor, 16680, Indonesia \\ ${ }^{2}$ Department of Aquatic Resources Management, Faculty of Fisheries and Marine Sciences, Bogor \\ Agricultural University, Bogor, 16680, Indonesia
}

\begin{abstract}
The development of coastal areas is growing rapidly in line with the high population growth that will threaten the continuity of coastal areas and ecosystems. Mangrove area located in the coastal area of Karawang Regency becomes an ecologically challenged area that greatly affects its sustainability. This study aims to examine mangrove ecosystems and community perspectives on the management of the mangrove ecosystems continuously and sustainably. The method used was a survey study at Nine Districts in Karawang Regency using the descriptive method with case study and perspective analysis on ten categories. Data were collected through interviews, observation and supported by secondary data. The description of this study was focused on mangrove ecosystem condition and community perspective in mangrove area management in coastal district Karawang. Data analysis used was a descriptive qualitative approach based on average with scales. The analysis results showed that most of the coastal communities in Karawang Regency strongly agree that; 1) The mangrove area in Karawang Regency is currently necessary/important to be managed to be sustainable, 2) The form of mangrove area management should involve all the local people, 3) There needs to be cooperation between the government and the local community in mangrove area management activities.
\end{abstract}

\section{Introduction}

Mangrove forests are biological natural resources that have various potentials that benefit human life, both directly and indirectly [1]. The management of coastal areas is usually done sectorally concerning managing one kind of coastal resource utilization conducted by one government agency. The management of this coastal area has a specific purpose, but in its implementation, it takes less consideration of ecological, geographic, and socio-cultural aspects, followed by low community perspectives. Such management may create a conflict of interest between interested sectors in carrying out development activities in the same

* Corresponding author: onosulistiono@gmail.com 
coastal area. In addition, such sectoral approaches generally pay little attention to the impact on other resource management, which can shut down the businesses in other sectors [2]. The people who live in the North Coastal Area of Karawang Regency depend on coastal and marine resources. High population growth encourages the growth of coastal resource utilization activities. This condition will have a positive impact on improving the economic community, but on the other hand, it can also cause various negative impacts. The existence of coastal resources utilization activities will cause environmental damage [3].

Karawang is one of the regencies located in the northern part of West Java Province, which has the potential of fish resources and the potential extensive mangrove forests. Mangrove forests in Karawang Regency are spread over 9 (nine) sub-districts, namely Pakisjaya, Batujaya, Tirtajaya, Cibuaya, Pedes, Cilebar, Tempuran, Cilamaya Kulon and Cilamaya Wetan sub-districts. However, the most considerable potential for mangrove forest colonies is in the sub-districts of Tirtajaya, Cibuaya, Pakisjaya, and Batujaya. The use of fishery products dominates the utilization of the mangrove ecosystem in 9 (nine) subdistricts. The conversion of mangrove forests into aquaculture locations, fishing boat mooring ports, and also settlements is a factor in the decline in the area of mangrove forests. The ongoing destruction and reduction of mangrove resources reduce fishery production and biodiversity and damage the stability of the surrounding marine coastal ecosystem [4].

Physical problems faced by the coastal area of Karawang is the destruction of coastal ecology due to the absence of coastal marine vegetation, so in general, the condition of the majority coastal abrasion. North Coast Karawang mainly in 5 districts, namely Cilamaya Kulon, Cilamaya Wetan, Tempuran, Cibuaya, and Tirtajaya mangrove plants are left very little. The mangrove population is less than $10 \%$ of the total coastline, and it is in a thin line constellation with an average width of fewer than 50 meters. Almost no mangrove ecology is qualified to be called a mangrove forest [5].

Mangrove ecology that decreases to thin is practically no longer able to protect the coastal and back coastal areas from the penetration of ocean currents, waves, and wind, so that the Northern Coast of Karawang is already much damaged by abrasion or coastal erosion, and in other places, there is massive and irregular sedimentation. In the cultivation area, mangrove trees that grow well are now rarely found in the ponds, so the fish in aquaculture ponds have often experienced deaths due to lack of oxygen, and water quality in aquaculture ponds are less good.

Planning of mangrove area management should start from awareness and perspective of the community residing in Karawang Regency coastal area to the mangrove area management.

Increasing public awareness in the management of an area is very important for the success of the management efforts of the area [6]. A coastal community perspective study will determine whether the community understands the mangrove area for the community's survival and the coastal environment concerning the management of the mangrove.

Several studies on mangrove and coastal areas of Karawang were carried out by several researchers, i.e., mangrove ecosystem related to fisheries productivity [7], coastal conditions and mangroves in Karawang [8], and coastal rehabilitation [9], [10]. At the same time, a study on community perceptions related to mangrove management in the regency has never been done.

\section{Methodology}

This study was carried out from October to December 2016. The study location was located in nine districts in the coastal district of Karawang, namely: Pakisjaya, Batujaya, Tirtajaya, Cibuaya, Pedes, Cilebar, Tempuran, Cilamaya Kulon and Cilamaya Wetan. This study was a survey study with a descriptive method which is a case study. The description of this study 
was focused on the community perspective in Karawang coastal mangrove ecosystem management.

The variable of this study is the emphasis on the criteria of community perspective on mangrove area management. This community assessment perspective variable is outlined in ten assessment criteria.

Populations and samples used adapted to the scope and objectives of the study. The population is the whole subject of study [11]. The population in this study was the whole coastal community that utilizes mangrove areas economically. The population in this study amounted to 270 heads of families who occupy the nine study sites and conduct activities utilizing mangrove ecosystems. Subjects in this study are homogeneous, so sampling was done as a representative, and the sampling was done randomly. The number of samples taken is determined based on the equation proposed by [12] as follows:

$$
n=\frac{N}{N d^{2}+1}
$$

Where $\mathrm{n}$ is the number of samples, $\mathrm{N}$ is the population, and $\mathrm{d}$ is the error rate. The selection of respondents was made by purposive sampling method, based on the consideration and purpose to know the community perspective in mangrove area management. Respondents that use the mangrove area to meet the needs of daily living were taken entirely. Data collection used primary data and secondary data.

The data analysis used a descriptive qualitative approach and its formulation as follows:

$$
\begin{gathered}
\overline{\mathrm{X}}=\sum \frac{\text { Score of Question } \mathrm{x} \text { Frequency of Score }}{\mathrm{n}} \\
R s=\frac{m-1}{m}
\end{gathered}
$$

is the mean score; $\mathrm{n}$ is the number of samples; Rs is the scale range, and $\mathrm{m}$ is the number of alternative answers for each item.

Step 1: Determine the scale range, ie:

$$
R s=\frac{5-1}{4}=0,8
$$

Step 2: The position of the assessment decision is:

Table 1. Mean score of community perspective scores.

\begin{tabular}{|c|c|}
\hline Mean Score & Information \\
\hline $1.0-1.8$ & Strongly Disagree \\
\hline $1.8-2.6$ & Disagree \\
\hline $2.6-3.4$ & Doubtful \\
\hline $3.4-4.2$ & Agree \\
\hline $4.2-5.0$ & Strongly Agree \\
\hline
\end{tabular}

Source: [13] 


\section{Results and discussion}

\subsection{Result}

\subsubsection{Mangrove condition in Karawang Coastal}

It has been analyzed changes in the land to find out how big the condition changes of the mangrove ecosystem and coastal ponds in the Karawang Regency with image interpretation methodology with object-based data processing techniques (OBIA) with eCognition Developer 9, ArcGIS 10.2, Ms. Excel 2016 software. The data source used was Landsat images with a scale of 1: 50,000 time series in 1995, 2005, and 2015 (Fig. 1).

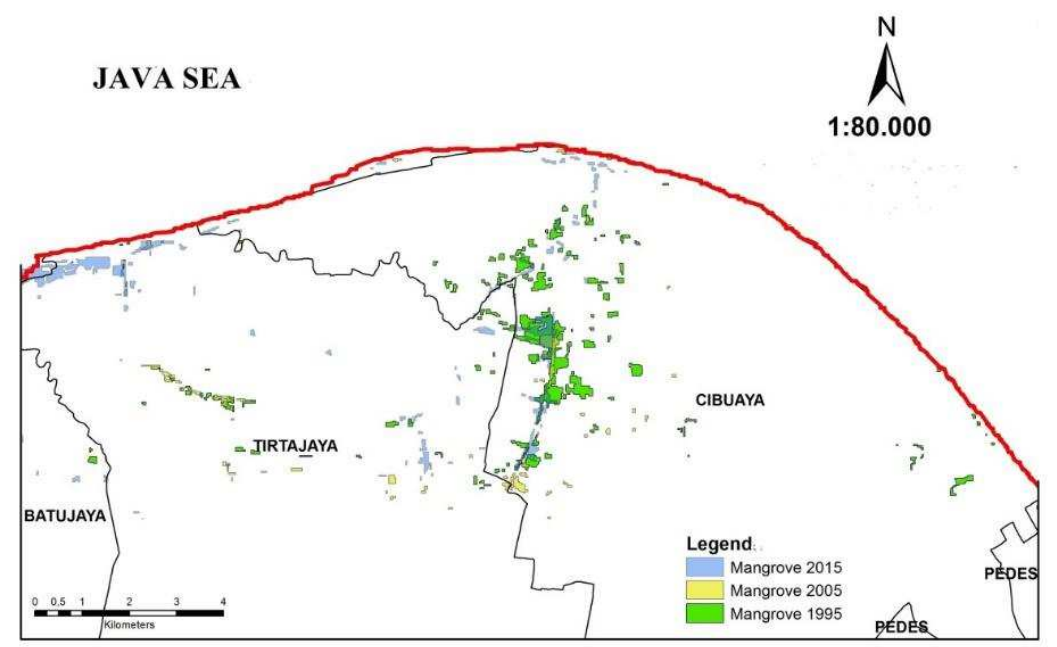

Fig. 1. Mangrove changed the layout from 1995, 2005, and 2015.

From the image interpretation and mapping result, it can be seen that mangroves' decrease area is starting from 1995 equal to 548,10 ha until the year 2005 equal to 296,74 ha. However, it starts to increase again in the year 2015, equal to 554,45 ha. Maybe this is due to several factors. Maybe this is due to several factors. By looking at the area of SIG obtained data compiled with statistical data that the mangrove area is indeed decreased. Mangrove area is a fundamental view from the ecological function. Various types of marine biota living in Karawang coastal mangrove areas are very dependent on the existence of the mangrove area. Mangrove creek waters are known as a nursery ground for a variety of aquatic animals that have substantial economic value, such as fish, shrimp, and shellfish. In addition, the leaves of mangroves in the mangrove area are an important source of organic material in the food chain in aquatic environments where leaf production can reach 7-8 tonnes/ha /year [14].

Mangrove area is a habitat for many species of birds, reptiles, mammals, and other types of creatures so that the mangrove area provides high biodiversity and germplasm. Mangrove area has functioned as a life support system too. Viewed from the physical function, a slid root system, and sturdy canopy, the mangrove area, also protects land from the onslaught of waves, tsunamis, hurricanes, and seepage seawater, and forces from other seas. Furthermore, it is stated that the economic potential of mangroves is obtained from three main sources, namely the results of the area, estuarine and coastal fisheries, and nature tourism. In addition, the mangrove area can be utilized for sustainable wood for building materials, charcoal, and 
paper raw materials. The mangrove area is also a supplier of fish larvae, shrimp, and other marine biotas.

\subsubsection{Condition of fisheries in Karawang Regency Coastal}

Regency Coastal has a high maritime potential. It can be seen from the long coastline at nine coastal districts and 34 coastal villages and from fish pond area of 18,273 hectares, 1,279 hectares of ponds, 10,580 hectares of rice fields, and 22 units of floating net pool [15]. In addition, Karawang Regency also has various supporting facilities to develop maritime potency, consisting of 1.381 fisheries households, 7,595 fisheries labor households, and 12 units of auction places for marine resources.

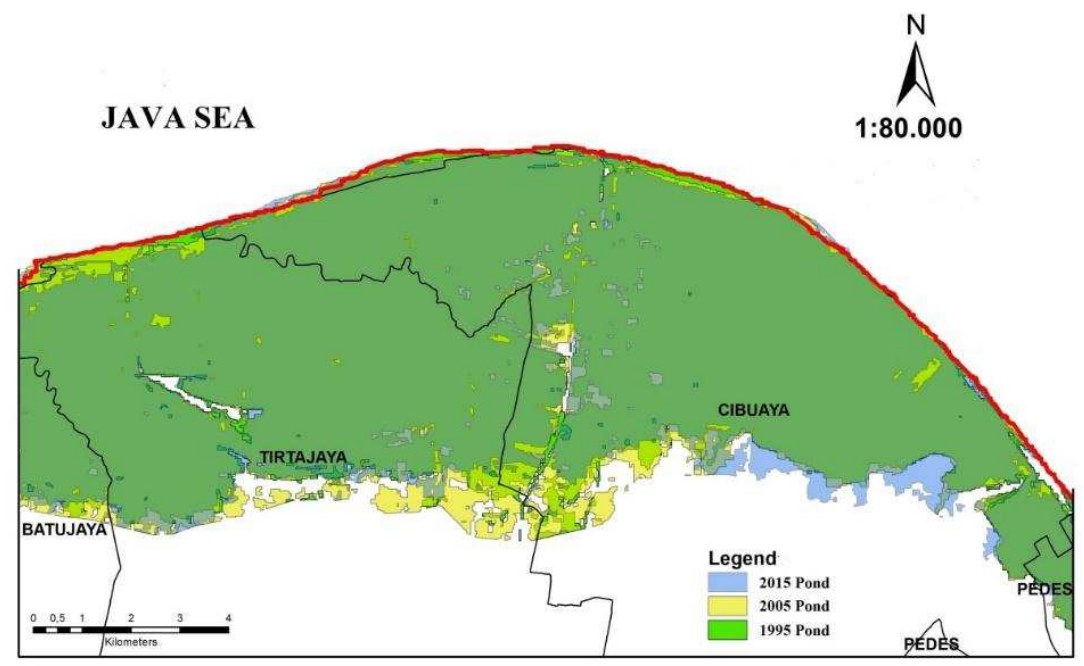

Fig. 2. Changes of fishery conditions 1995, 2005, and 2015.

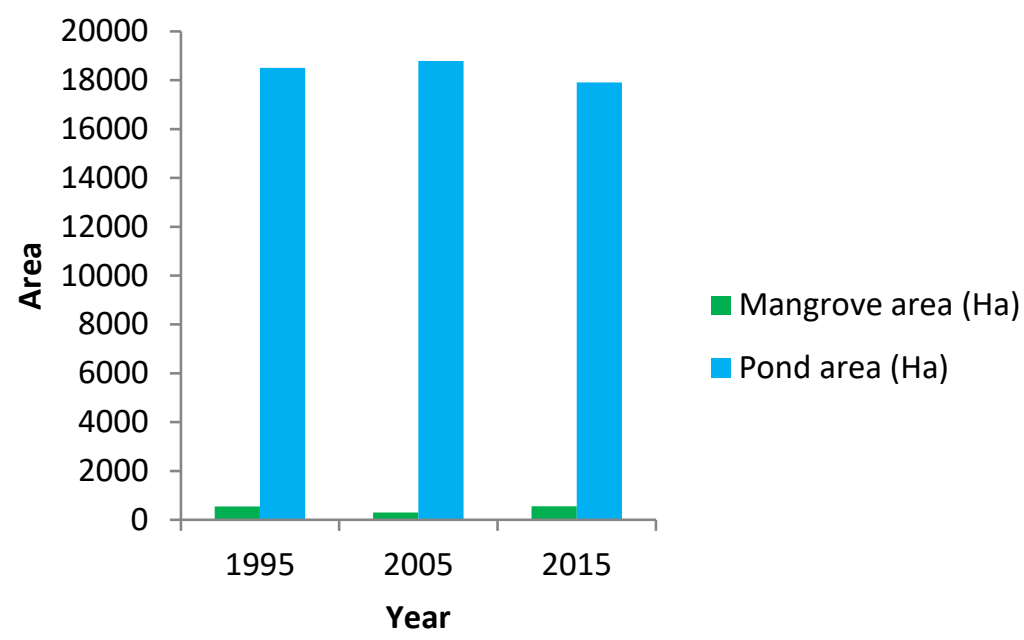

Fig. 3. Graph changes of mangrove Area and Fishpond Area. 
From the existing conditions regarding the relationship of mangrove and productivity of aquaculture and capture fisheries data obtained that there is a decrease in productivity of aquaculture and capture fisheries along with the decrease of mangrove area. Existing data indicate that in 1995,2005 , and 2015, the following table decreased.

Table 2. Table of the mangrove condition and fish production changes.

\begin{tabular}{|c|c|c|c|c|}
\hline No & Year & $\begin{array}{c}\text { Mangrove Area } \\
\text { (ha) }\end{array}$ & $\begin{array}{c}\text { Aquaculture } \\
\text { (Ton/Year) }\end{array}$ & $\begin{array}{c}\text { Capture Fisheries } \\
\text { (Ton/Year) }\end{array}$ \\
\hline 1 & 1995 & 548.10 & 30469.6 & 10531.03 \\
\hline 2 & 2005 & 296.74 & 33985.91 & 5385.5 \\
\hline 3 & 2015 & 554.45 & 39113.65 & 8499.87 \\
\hline
\end{tabular}

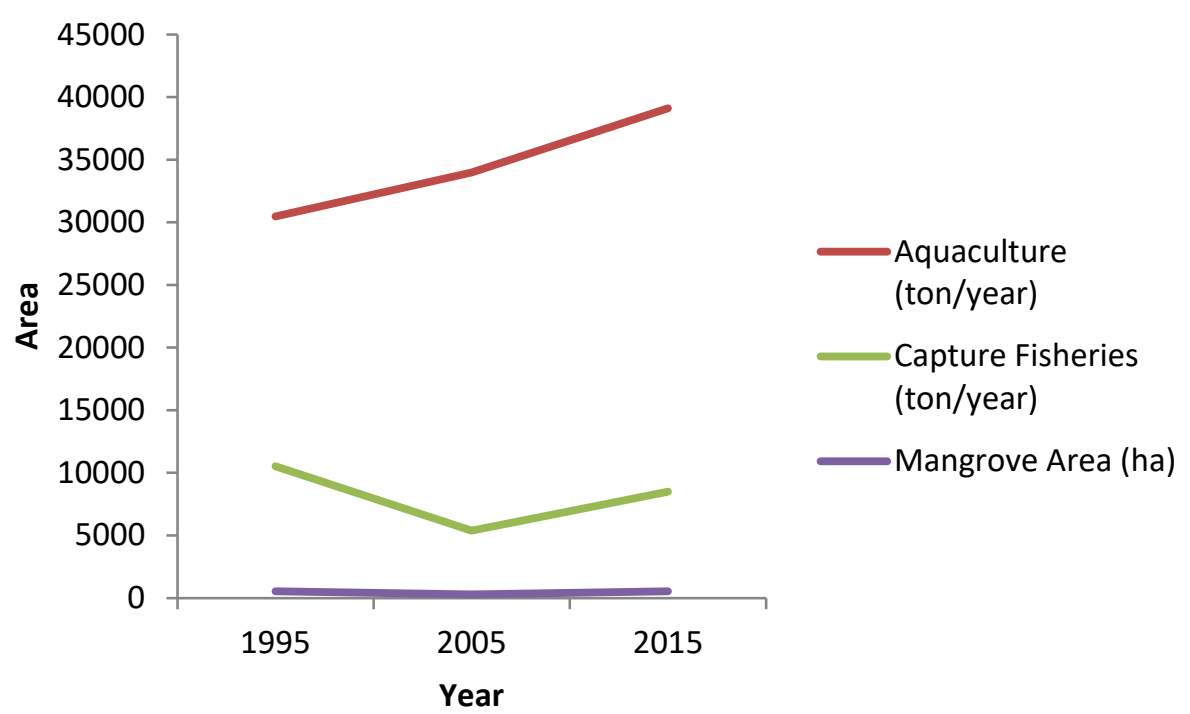

Fig. 4. Correlation between Mangrove Area and Fishery Production.

From these two results, it is evident that mangrove function is not optimal because the current results are still far from ideal conditions, so there needs to be special management that is integrated and sustainable to achieve optimal results.

From the results of this comparison can be seen a significant change that allegedly other factors affect the decline in productivity of Aquaculture and Capture Fisheries. Some sources found that there is a virus that causes death in shrimp, so after 2004, shrimp productivity has decreased drastically.

By looking at this condition, it is regrettable if a management strategy is not immediately prepared to support the creation of other economic resources such as fisheries. The form of fishery cultivation that can make the community's economy move aside from agriculture and plantation will have a more positive impact besides its own mangrove function as a sediment holder that can perform coastal conservation functions. 


\subsection{The perspective of communities to mangrove area management in Karawang Coastal}

Coastal communities should feel responsible for sustaining sustainable resources [16]. To achieve these objectives, coastal communities need to be supported by the quality of human resources as a subject in coastal area management.

There are ten assessment criteria used to analyze the perspective of communities in Karawang coastal on mangrove area management, and the criteria are as follows:

1. Karawang Coastal Mangrove Area needs/important to be managed in order to be sustainable (P1).

2. The form of mangrove area management should involve all local people (P2).

3. There needs to be cooperation between the government and local people in managing the mangrove area (P3).

4. There is a need for regulation in mangrove area management (P4).

5. Violation of the rules of mangrove area management should be given sanction or punishment (P5).

6. The form of management does not have to be following local wisdom (customs/culture) owned by local people (P6).

7. Coastal mangrove area management in Karawang will hinder the development of coastal and marine areas. For example, the construction of residential housing and agricultural land will be hindered (P7).

8. Management of the mangrove area will limit the local population to utilize the mangroves as well as the existing resources (P8).

9. Only a part of locals or government will benefit / advantage over their management of mangrove areas in the Karawang Coastal (P9).

10. Migrant communities did not have to obey the rules in the management of Karawang coastal mangrove areas (P10).

The ten criteria are then scored based on community assessment to identify the position of the community perspective assessment decision, and the assessment decision is based on an average score. Based on the position (indicator) of decision making and compared with the average score of each question perspective. The results of community perspectives in Karawang coastal can be translated for each district in Table 3 below.

Table 3. Criteria of respondents perspective assessment per district to mangrove areas management in Karawang coastal.

\begin{tabular}{|c|c|c|c|c|c|c|c|c|c|c|}
\hline \multirow{2}{*}{ Districts } & \multicolumn{10}{|c|}{ Assessments Criteria } \\
\cline { 2 - 14 } & P1 & P2 & P3 & P4 & P5 & P6 & P7 & P8 & P9 & P10 \\
\hline Pakisjaya & 4.5 & 4.37 & 4.4 & 4.17 & 3.57 & 2.73 & 3.27 & 3.33 & 3.63 & 3.4 \\
\hline Batujaya & 4.53 & 4.43 & 4.43 & 4.07 & 3.83 & 3 & 3.6 & 3.57 & 3.67 & 4 \\
\hline Tirtajaya & 4.4 & 4.3 & 4.23 & 4.07 & 3.73 & 3.63 & 3.47 & 3.73 & 3.97 & 3.97 \\
\hline Cibuaya & 4.4 & 4.37 & 4.37 & 4.2 & 4.1 & 3.5 & 3.9 & 3.97 & 4.1 & 4.27 \\
\hline Pedes & 4.83 & 4.2 & 4.2 & 4.2 & 4.17 & 2.83 & 1.63 & 1.8 & 1.8 & 1.67 \\
\hline Cilebar & 4.7 & 4.53 & 4.43 & 4.43 & 4.07 & 3.83 & 3 & 3.6 & 3.57 & 3.67 \\
\hline Tempuran & 4.6 & 4.43 & 4.43 & 4.07 & 3.83 & 3 & 3.6 & 3.57 & 3.67 & 2.56 \\
\hline Cilamaya Kulon & 4.54 & 3.9 & 3.97 & 4.1 & 4.43 & 4.07 & 3.83 & 3 & 3.6 & 3.57 \\
\hline Cilamaya Wetan & 4.36 & 4.24 & 4.23 & 4.25 & 4.17 & 2.83 & 1.63 & 3.8 & 3.8 & 3.67 \\
\hline
\end{tabular}

Based on the results of communities perspective analysis of mangrove area management in each district as seen in the table above, the overall results of community perspectives in Karawang coastal can be seen in the following table. 
Table 4. Assessment of communities perspective on mangrove area management in Karawang coastal.

\begin{tabular}{|c|c|c|c|}
\hline No & Assessment Criteria & Mean Score & Information \\
\hline P1 & $\begin{array}{l}\text { Karawang Coastal Mangrove Area needs/is } \\
\text { important to be managed in order to be } \\
\text { sustainable. }\end{array}$ & 4.54 & Strongly Agree \\
\hline $\mathrm{P} 2$ & $\begin{array}{l}\text { The form of mangrove area management } \\
\text { should involve all local people }\end{array}$ & 4.307 & Strongly Agree \\
\hline $\mathrm{P} 3$ & $\begin{array}{l}\text { There needs to be cooperation between the } \\
\text { government and local people in the } \\
\text { management of the mangrove area }\end{array}$ & 4.298 & Strongly Agree \\
\hline P4 & $\begin{array}{c}\text { There is a need for regulation in mangrove } \\
\text { area management }\end{array}$ & 4.173 & Agree \\
\hline P5 & $\begin{array}{c}\text { Violation of the rules of mangrove area } \\
\text { management should be given sanction or } \\
\text { punishment }\end{array}$ & 3.98 & Agree \\
\hline P6 & $\begin{array}{l}\text { The form of management does not have to be } \\
\text { in accordance with local wisdom } \\
\text { (customs/culture) owned by local people }\end{array}$ & 3.268 & Doubtful \\
\hline P7 & $\begin{array}{l}\text { Coastal mangrove area management } \\
\text { in Karawang will hinder the development of } \\
\text { coastal and marine areas. For example, the } \\
\text { construction of residential housing and } \\
\text { agricultural land will be hindered }\end{array}$ & 3.103 & Doubtful \\
\hline P8 & $\begin{array}{l}\text { Management of the mangrove area will limit } \\
\text { the local population to utilize the mangroves } \\
\text { as well as the existing resources. }\end{array}$ & 3.374 & Doubtful \\
\hline P9 & $\begin{array}{l}\text { Only a part of locals or government will } \\
\text { benefit / advantage over their management of } \\
\text { mangrove areas in the Karawang Coastal. }\end{array}$ & 3.534 & Agree \\
\hline $\begin{array}{c}\mathrm{P} 1 \\
0\end{array}$ & $\begin{array}{l}\text { Migrant communities did not have to obey the } \\
\text { rules in the management of Karawang } \\
\text { coastal mangrove areas }\end{array}$ & 3.42 & Agree \\
\hline
\end{tabular}

\subsection{Discussion}

Mangrove forests are commonly found throughout the Indonesian coast and live and grow in areas with tidal connections seeping on river banks [17]. Mangrove forests are a type of forest overgrown with mangroves (mangroves) that are typical along the coast or river estuaries and are affected by tidal water [18]. The area of mangrove forest in Karawang Regency in 1995, 2005, and 2015 are 548.10 hectares, 296,74 hectares, and 554.45 hectares, spread in some areas, namely nine coastal districts, namely District Pakisjaya, Batujaya, Tirtajaya, Cibuaya, Pedes, Cilebar, Tempuran, and District Cilamaya Kulon - Wetan. Mangrove forests have a dual function and are a very important link in maintaining the balance of the biological cycle in water [19].

As one of the tropical wetlands with easy access and high use of biodiversity and land components, Mangrove forests have made the resource a tropical resource that its sustainability will be threatened [20] and become one of the centers of global environmental issues. Conversion of mangrove forests continues to increase to be used as agricultural land or fish/shrimp ponds, thus causing a decline in the productivity of these ecosystems [21]. 
Despite having suffered severe damage due to the transfer of functions to intensive shrimp culture, the success of reforestation of mangrove forest in Karawang is due to the very high awareness of the mangrove forest function, especially as the storm protection of the flood and the wind. Besides, in 2005 the government intensively returned in reforesting the mangrove.

[22] suggested that mangroves along coasts and rivers generally provide habitat for a wide variety of fish. Based on this, for Karawang Regency itself, the dominant mangrove species are Rhizophora sp., Avicenia sp., Sonneratia sp., and Bruguiera sp., where the coastal potential for mangrove reforestation is 270 hectares or an average of 30 hectares in each district. However, several reforestation programs have been carried out, showing a low success rate. This is partly due to low community participation due to land conditions that do not support plant growth and less intensive maintenance.

The results of surveys and interviews with the community showed that the successful reforestation of mangrove forests in coastal areas of Karawang positively impacts the economy of society. From the data of coastal community activities as fishermen in the last ten years shows a very significant development, the number of fish and shrimp producers and fishermen near mangrove forests increased more than two times compared to the previous year.

The potential of the coastal coastline north of Karawang regency is quite big, about 84.23 $\mathrm{km}$, stretching in 9 (nine) districts with a pond area \pm 18.000 hectares. Based on the results of Fisheries and Marine Affairs data in 2015, the Karawang Regency has a large fishing potential, with $84.23 \mathrm{~km}$ long coast, 436,00 km long river, reaching 119.90 hectares. While in the fishery sector, Karawang Regency has an 18,273.30-hectare pond area, 1,188,19hectare pond, 10,580,80 hectares of rice-fish, and a floating net cage of 99 units.

With this potential, fish production in Karawang Regency is estimated to reach 46 thousand tons per year, which is generated from the aquaculture sector reaching 38 thousand tons and capture fisheries of 7 thousand tons. At the same time, the level of consumption of fishery products in the Karawang Regency has reached 26.01 kilograms per capita per year.

In addition, the length of the coastline and the number of rivers and estuaries has made the Karawang Regency a place where fishing boats and fishermen from abroad. Every year the fleet of fishermen who dock and auction in Karawang regency always increases. In 2011, it was estimated there are 1.203 household production (RTP) fishermen, 5,417 household production laborers (RTBP) fishermen, 7,561 RTP pond ponders who depend on their lives. Based on the data, the total income of fishermen and fish farmers in the Karawang Regency is estimated to have reached $\mathrm{Rp} 21.4$ million for fishermen and $\mathrm{Rp} 13.35$ million for fish farmers.

Based on Table 2, it is known that cultivation and capture fisheries production from 1995 , 2005, and 2015 showed an increase except in 2005 decreased production for capture fishery which is 10531,03 ton/year (in 1995), 5385, 05 ton/year (in 2005) and 8499,87 ton/year (in 2015). The result of production is dominated by the cultivated fishery, which always increases from year to year that is 30469,6 tons/year, 33985,91 tons/year, and 39113,65 tons/year. This situation is similar to the [23] study that the decrease of mangrove habitat shows the exact decrease of shrimp production both amount and profit, so that mangrove is as important as input of shrimp fishery production.

The results of the analysis in Table 4 show that coastal communities in Karawang coastal area strongly agree that; 1) The mangrove area in the Karawang coastal is currently necessary/essential to be managed in order to be sustainable, 2) The mangrove area management should involve all the local people, 3) There needs to be cooperation between the government and the local people in mangrove area management activities. Based on the prospective analysis of the three criteria above, coastal communities of Karawang understand the importance of mangrove areas in their survival. They realize that the mangrove area needs 
to be appropriately managed in order to maintain its sustainability. They also want participation in government programs from the district/ village to the local government to manage sustainable mangrove areas. The interviews and FGDs conducted in Karawang coastal area also show that most of the community is very enthusiastic about maintaining and preserving the mangrove area. This provides a very important indication in the management of sustainable mangrove areas.

Karawang coastal communities agree that the need for rules in the management of mangrove areas and violations of the rules of mangrove area management should be given sanctions or punishment. Communities' knowledge is very less on rules and sanctions in the management of mangrove areas. Through this study, people agree if local governments make written rules in the management of mangrove areas. They also agree to obey the rules made to preserve the mangrove area. If they violate the rules, they are willing to be subject to sanctions or punishment. During this local government, through agencies associated with coastal areas consisted of Fisheries and Marine Affairs, Environmental Agency, and Forest Service of Karawang Regency.

However, for the prospective assessment criteria, 1) The form of management should not be following local wisdom (customs/culture) owned by local people, 2) Management of mangrove areas in Karawang coastal area will hinder the development of coastal areas and the sea. For example, residential development of the population and agricultural land will be hindered. 3) Management of the mangrove area will limit the local population to utilize mangroves and the resources within which the community is still doubtful to provide an assessment. The results of these three assessment criteria indicate that the community has only used mangrove areas without any rules and sanctions so that they are free to use the mangrove area and its ecosystem. This result is obvious from field observations where human activities mostly damage mangrove areas. They cut down mangrove trees to be used as fuel, home construction, and household appliances. Some of the mangrove trees are cut down to build people's homes on land and coastal borders. People are hesitant to answer these three criteria because they also badly need mangrove trees to support their daily lives. The destruction was primarily due to economic pressures [24]. So far, people in Karawang coastal are lack knowledge about the existence of mangrove areas and their benefits and efforts to be done to preserve the mangrove area, so the assessment of the community is still in doubt.

Karawang coastal communities agree that; 1) Only a few residents or the government will benefit from the mangrove area management in Karawang coastal area, and 2) Migrant communities do not need to obey the rules in mangrove area management in Karawang coastal area. Both of these assessment criteria are also based on the lack of community knowledge on the management of mangrove areas that are very valuable economic and ecological for the communities.

Assessment of communities' perspective on mangrove area management is also strongly influenced by the level Mangrove areas management in Karawang coastal must be appropriately implemented. This condition will significantly support the conservation of mangrove areas in a sustainable manner. In general, communities should be given knowledge in counseling and training on mangrove area management for the sustainability of mangrove areas. Given the vulnerability of mangrove forests and communities activities that live around the mangrove forests to maintain their natural resources, the role of the community in preserving and even developing mangrove forests into an environment forests supporting the availability of marine natural resources becomes very important. Communities' perspectives need to be directed to continuously maintain and preserve the existence of the area along with the mangrove ecosystem. 


\section{Conclusion and recommendations}

\subsection{Conclusion}

Based on the results of the study, data analysis conducted, and discussion can be drawn some conclusions, that is Mangrove Condition in Karawang Coastal area of mangrove forest in Karawang regency in 1995, 2005, and 2015 are 548.10 hectares, 296,74 hectares, and 554.45 hectares. The dominant mangrove species in the Karawang regency are Rhizophora sp, Avicennia sp, Sonneratia sp, And Bruguiera sp.

Cultivation and capture fisheries production from 1995, 2005, and 2015 showed an increase except in 2005 decreased production for capture fishery is 10531,03 ton/year, 5385, 05 ton/year, and 8499,87 ton/year. The result of production is dominated by the cultivated fishery, which always increases from year to year that is 30469,6 tons/year, 33985,91 tons/year, and 39113,65 tons/year.

Karawang coastal communities agree that the mangrove area management in Karawang coastal is essential and needs sustainability.

\subsection{Recommendations}

The recommendations of this study are Karawang coastal communities should be given knowledge about the importance of mangrove benefits and mangrove area management in a sustainable manner. Communities need to be involved together with the government in the sustainable management of mangrove areas. Rules and sanctions should be made in a written arrangement in a PERDA or PERDES for mangrove area management.

\section{References}

1. A. Kustanti, Mangrove forest management (IPB Press, Bogor, 2011)

2. H.R. Dahuri, J. Rais, S.P. Ginting, M.J. Sitepu, Integrated coastal and marine resource management (PT Pradnya Paramita, Jakarta, 2004)

3. A. Fauzi, S. Anna, Modeling of fisheries and marine resources for policy analysis (PT. Gramedia Pustaka Umum, Jakarta, 2005)

4. B.H. Daru, K. Yessoufou, L.T. Mankga, T.J. Davies, PLoS One 8, 6 (2013)

5. Department of Marine and Fisheries, Report on marine and fishery potential (Government of Kab. Karawang, Karawang, 2015)

6. D. Ayunita, T.D. Hapsari, Undergraduate Thesis, Semarang (ID): Diponegoro University (2012)

7. Y.A. Nugraha, Sulistiono, H.A. Susanto, C.P.H. Simanjuntak, D.M. Wildan, IOP Conf. Ser. Earth Environ. Sci. 8002021

8. M. Nopiana M, F. Yulianda, Sulistiono, A. Fahrudin, G. Yulianto, AACL Bioflux 13, 6 (2020)

9. M. Nopiana, F. Yulianda, Sulistiono, A. Fahrudin, AACL Bioflux 13, 2 (2020)

10. M. Nopiana, F. Yulianda, Sulistiono, A. Fahrudin, G. Yulianto, AACL Bioflux 14, 1 (2021)

11. S. Arikunto, Prosedur penelitian (Publisher Rineka Cipta, Jakarta, 2010)

12. Ernawati, Statistical method (in Bahasa Indonesia) (Transito, Bandung, 1997) 
13. H. Umar, Human resources study in organizations (in Bahasa Indonesia) (PT Gramedia. Pustaka Utama, Jakarta, 2005)

14. A. Nontji, Archipelago sea (in Bahasa Indoensia) (Djambatan, Jakarta, 2000)

15. BAPPEDA Regency Karawang, Spatial plan of Karawang District 2011-2031. Regency Karawang (BAPPEDA, Karawang, 2011)

16. A. Dian, D.H. Trisnani, J. Sepa, 9, 1 (2012)

17. M.S. Tarigan, Makara Sci. 2, 108 - 112 (2008)

18. P.J. Hogarth, The biology of mangroves (Oxford University Press, Oxford, 1999)

19. H.J.D. Waas, B. Nababan, Trop. Mar. Sci. Technol. 2, 1 (2010)

20. I. Valiela, J.L. Bowen, J.K. York, Bioscience 51, 10 (2001)

21. R. Dave, Tropical Res. Bulletin 25, 7 - 13 (2006)

22. Muryani C., Ahmad, Nugraha S., Utami T., Journal of People and Environment, 18, 2 (2011)

23. E. Barbier, I. Strand, Valuing mangrove-fishery linkages - a case study of Campeche, Mexico (Milano, Milan, 1997)

24. B.B. Walters, P. Ronnback, J.M. Kovacs, B. Crona, S.A. Hussain, R. Badola, J.H. Primavera, E. Barbier, F. Dahdouh-Guebas, Aquat. Bot. 89 (2008) 